\title{
The Research on Influencing Factors of Stock Price Fluctuation of Listed Companies in China Based on PCA-Multiple Regression
}

\author{
Yan Ma \\ Faculty of Accounting, Anhui University of Finance and Economics, Bengbu, China \\ Email:yanma@163.com
}

How to cite this paper: Ma, Y. (2021). The Research on Influencing Factors of Stock Price Fluctuation of Listed Companies in China Based on PCA-Multiple Regression. Open Journal of Social Sciences, 9, 305-315. https://doi.org/10.4236/jss.2021.93020

Received: February 19, 2021

Accepted: March 21, 2021

Published: March 24, 2021

Copyright (๑) 2021 by author(s) and Scientific Research Publishing Inc. This work is licensed under the Creative Commons Attribution International License (CC BY 4.0).

http://creativecommons.org/licenses/by/4.0/

\section{(c) (i) Open Access}

\begin{abstract}
Taking the transportation industry as an example, aiming at the research problem of influencing factors of stock price fluctuation of listed companies in China, this paper selects 70 listed companies from A-share companies of Shanghai Stock Exchange, eliminates ST companies and companies with incomplete data, and takes the average closing price of each trading day of the remaining 63 listed companies from May 1 to June 30, 2020 as the explanatory variable. After that, the principal component comprehensive evaluation method is used to calculate the main factors affecting the stock price fluctuation of listed companies in the transportation industry as the explanatory variable. Eviews9.0 was used to carry out multiple linear regression analysis on the data, and the analysis results showed that the index data related to debt paying ability, asset appreciation ability and profitability were important factors affecting the stock price fluctuations of the listed companies in the transportation industry.
\end{abstract}

\section{Keywords}

Stock Price, Financial Indicators, Panel Data, Principal Component Regression

\section{Introduction}

The capital market is complicated, and the public and transparent information disclosure is the premise of the effective operation of the capital market. The financial information contained in the enterprise annual report is the main source of the stock market information and the direct factor affecting the stock price. With the continuous improvement of residents' living standards and the increasing accumulation of wealth, more and more people begin to choose to in- 
crease their own wealth through investment and financial management. Therefore, the study of the impact of financial indicators on stock prices is not only helpful for stock investors to make reasonable investment decisions, but also helpful to further improve the accounting information disclosure system. As the basic industry of China's economy, the transportation industry serves as the backbone of the development of the national economy and carries the task of human and material transportation throughout the country. Therefore, it is of practical significance to study the stock prices of listed companies in the transportation industry. From the perspective of finance, this paper takes the 63 transportation companies in Shanghai Stock Exchange as examples, explores the correlation between the historical financial information publicly disclosed by companies and stock prices, and analyzes the main factors affecting stock prices, so as to help stock investors make more reasonable investment decisions.

\section{Literature Review}

Since the emergence of empirical studies on the relationship between accounting information and stock prices in the 1960s, Chinese and Western scholars have shown great interest in this issue.

Xiang \& Dai (2019) used multiple linear regression analysis, selected eight financial indicators such as return on equity and carried out linear regression analysis with stock price, and concluded that there was a great correlation between the profitability of listed companies and stock price. Nie Miaomiao (Nie, 2018) extracted 6 principal component factors from 16 financial factors in the New Third Board market by comprehensive use of principal component analysis, and analyzed the correlation between them and stock price. Finally, it was concluded that the factor of asset appreciation ability was equal to the stock price, showing a strong correlation. Jing Fangfang (Jing, 2017), based on the improved GARCH-MIDAS model and by comparing the multi-factor mixing model and the single-factor mixing model, analyzed the long-term components of China's stock market price fluctuations, and put forward policy suggestions accordingly.

According to the research of most scholars, it is found that the selection of financial factors affecting stock price fluctuation of listed companies is mainly based on subjective factors. Therefore, this paper will use literature research collection is generally accepted that a larger impact on stock price volatility of financial indicators, using principal component analysis (PCA) to extract principal component, multiple index finally combined with principal component reduction shares the company different ability index of the multivariate linear regression model, and combined with related financial background correlation analysis, provide a reference for investors make investment decisions.

\section{Model Setting}

\subsection{Financial Factors that Affect Stock Prices}

The selection of financial indicators is an important link in the study of stock 
price fluctuations. Through literature review and considering many influencing factors, this paper selects 12 financial indicators data from the 2019 annual reports of Shanghai A-share market enterprises as explanatory variables, (Sha, 2018) which are as follows:

1) Net cash flow per share, which reflects the amount of cash created by the company using capital per share; 2) Return on equity, which reflects the income level of shareholders' equity, is used to measure the efficiency of using the company's own capital; 3) Operating profit margin, which can comprehensively reflect the operating efficiency of an enterprise or an industry; 4) Current ratio, which is used to measure the ability of the enterprise's current assets to be turned into cash for repayment of liabilities before the maturity of short-term debts; 5) Quick ratio, which is used to measure the ability of an enterprise's current assets to be immediately turned into cash for repaying current liabilities; 6) The growth rate of net profit refers to the growth rate of the net profit of the enterprise in the current period compared with the net profit of the previous period; 7) the growth rate of net assets, reflecting the expansion speed of the enterprise's capital scale; 8 ) The growth rate of total assets, reflecting the growth of the enterprise's current asset scale; 9) Inventory turnover, which reflects the turnover speed of inventory, namely whether the liquidity of inventory and the amount of inventory funds are reasonable; 10) Accounts receivable turnover rate, is to measure the enterprise accounts receivable turnover speed and management efficiency of the index; 11) Total asset turnover is an indicator to measure the ratio between asset investment scale and sales level; 12) Net profit cash content refers to the ratio of net cash flow generated in production and operation to net profit.

\subsection{Selection of Variables}

Due to the time of the disclosure of the annual report of listed companies in China for a year on January 1 solstice on April 30, and the financial information reflected in the annual report will have an impact on the second day of the reporting date of the next year's annual financial statement, this paper will choose the average closing price P of each trading day during May 1, 2020 solstice June 30 of listed companies as the explained variable, representing the stock price after the disclosure of the annual report in 2020.

This paper first selects 12 financial indicators from the 2019 annual reports of Shanghai A-share market enterprises, of which the specific meanings are shown in Table 1 (Li, 2014).

Considering the correlation between different financial indicators, this paper uses principal component analysis to extract five principal components from the 12 financial indicators, which are respectively named as solvency factor, asset appreciation ability factor, profitability factor, operating ability factor and profit appreciation ability factor according to their correlation with financial indicators (Hao, 2018). These five principal components are taken as new explanatory 
Table 1. Selection and distribution of financial indicators.

\begin{tabular}{|c|c|c|}
\hline The variable name & symbol & Definition of variables \\
\hline Net cash flow per share & $X_{1}$ & Net cash inflow or net expenditure/Total equity \\
\hline Return on equity & $X_{2}$ & Net Profit/Net Assets \\
\hline Operating profit margin & $X_{3}$ & Operating profit/total business income $\times 100 \%$ \\
\hline Current ratio & $X_{4}$ & Total current assets/Total current liabilities $\times 100 \%$ \\
\hline Quick ratio & $X_{5}$ & Quick assets/Current liabilities \\
\hline Growth rate of net profit & $X_{6}$ & $\begin{array}{l}\text { (Net profit of current period - Net profit of previous } \\
\text { period)/Net profit of previous period } \times 100 \%\end{array}$ \\
\hline Growth rate of net assets & $X_{7}$ & $\begin{array}{l}\text { (ending net assets }- \text { beginning net assets)/beginning net } \\
\text { assets) } \times 100 \%\end{array}$ \\
\hline Growth rate of total assets & $X_{8}$ & $\begin{array}{l}\text { Growth of total assets this year/total assets } \\
\text { at the beginning of the year } \times 100 \%\end{array}$ \\
\hline The turnover rate of inventory & $X_{9}$ & Operating costs/average balance of inventory \\
\hline $\begin{array}{l}\text { The turnover rate of accounts } \\
\text { receivable }\end{array}$ & $X_{10}$ & $\begin{array}{l}\text { Current net sales revenue/(accounts receivable } \\
\text { balance at the beginning + accounts receivable } \\
\text { balance at the end)/2 }\end{array}$ \\
\hline The turnover rate of total assets & $X_{11}$ & Net Operating Income/Average Total Assets \\
\hline
\end{tabular}

variables and are respectively represented by $F_{1}, F_{2}, F_{3}, F_{4}$ and $F_{5}$. The specific meanings are shown in the table below. See Table 2.

$$
P=\beta_{0}+\beta_{1} F_{1}+\beta_{2} F_{2}+\beta_{3} F_{3}+\beta_{4} F_{4}+\beta_{5} F_{5}+\mu
$$

In the formula, the extracted five principal components are taken as explanatory variables, and the stock prices of listed transportation companies in Shanghai A-share market after the disclosure of their 2020 annual report are taken as explanatory variables to study the correlation between financial factors and the stock prices of listed transportation companies in Shanghai A-share market after the disclosure of their annual report.

\section{Model Estimation}

The principal component regression method is used to estimate the parameter model, (Yao \& Wang, 2014) so as to reveal the main financial factors affecting the stock prices of listed companies in the transportation industry in Shanghai A-share market and their influence degree. The specific steps are as follows:

1) Due to the large number of explanatory variables selected, in order to avoid multicollinearity, principal component analysis was used to reduce the dimension of multiple explanatory variables, that is, five principal components were extracted from 12 correlated financial indicators; 2) With stock price data as explained variables and five principal components extracted as explanatory variables, the model parameters of the regression equation were estimated and tested; 3) Substitute the principal component function into the estimated regression equation that passes the test, and conduct structural analysis accordingly. 
Table 2. Principal components extracted.

\begin{tabular}{|c|c|c|}
\hline $\begin{array}{l}\text { The main } \\
\text { factor }\end{array}$ & Name of factor & The financial indicators included \\
\hline$F_{1}$ & Solvency factor & Current ratio, Quick ratio \\
\hline$F_{2}$ & $\begin{array}{l}\text { Asset appreciation } \\
\text { ability factor }\end{array}$ & $\begin{array}{l}\text { Growth rate of total assets, Growth rate } \\
\text { of total assets, Net cash flow per share }\end{array}$ \\
\hline$F_{3}$ & Profitability factor & $\begin{array}{c}\text { Return on equity, Operating profit margin, } \\
\text { Net profit cash content }\end{array}$ \\
\hline$F_{4}$ & $\begin{array}{l}\text { Operational } \\
\text { capacity factor }\end{array}$ & $\begin{array}{l}\text { The turnover rate of inventory, } \\
\text { The turnover rate of total assets }\end{array}$ \\
\hline$F_{5}$ & $\begin{array}{l}\text { Developmental } \\
\text { ability factor }\end{array}$ & $\begin{array}{l}\text { The turnover rate of accounts receivable, } \\
\text { Growth rate of net profit }\end{array}$ \\
\hline
\end{tabular}

\section{The Empirical Analysis}

\subsection{Selection of Samples}

This paper studies the stock price fluctuation of Shanghai A-share transportation companies. Transportation industry is the basic industry of our country and an important industry connecting various industries. In the selection of data samples, some ST companies and companies with incomplete data were excluded. Finally, 63 listed companies were selected from 70 listed companies. All index data were obtained from the Resset Financial Research Database.

\subsection{Principal Component Analysis}

This paper studies the stock price fluctuation of Shanghai A-share transportation companies. Transportation industry is the basic industry of our country and an important industry connecting various industries. In the selection of data samples, some ST companies and companies with incomplete data were excluded. Finally, 63 listed companies were selected from 70 listed companies. All index data were obtained from the Resset Financial Research Database.

It is generally believed that when KMO statistics are higher than 0.5 , principal component analysis is appropriate. It can be seen from Table 3 that $\mathrm{KMO}$ values of 12 financial indicators are 0.502 , higher than 0.5 but lower than 0.6. In Bartlett sphericity test, statistical significance level is less than 0.01 . According to the comprehensive analysis, it is feasible to carry out factor analysis on 12 individual financial indicators (Dong, 2011).

The data was imported into SPSS for dimensionality reduction to get the total variance explained. Based on the eigenvalue greater than 1, five common factors were extracted by default in principle. As shown in Table 4, the first five common factors accounted for $73.939 \%$ of the total information, so the extracted five principal components could better explain the information contained in the original variables. See Table 3.

Table 5 shows the rotated factor load matrix, in which the first common factor has the largest correlation coefficient with the current ratio and the quick ratio, 
Table 3. KMO and bartlett tests.

\begin{tabular}{|c|c|c|}
\hline \multicolumn{2}{|c|}{ Sampling the Kaiser-Meyer-Olkin measure of adequacy } & 0.502 \\
\hline \multirow{3}{*}{ Bartlett's test for sphericity } & The approximate chi-square & 361.330 \\
\hline & df & 66 \\
\hline & Sig. & 0.000 \\
\hline
\end{tabular}

Table 4. Total variance of the interpretation.

\begin{tabular}{|c|c|c|c|c|c|c|c|c|c|}
\hline \multirow[b]{2}{*}{ Composition } & \multicolumn{3}{|c|}{ Initial Eigenvalue } & \multicolumn{3}{|c|}{ The squared sum of the extracted loads } & \multicolumn{3}{|c|}{ The sum of the squares of the rotating loads } \\
\hline & totals & $\begin{array}{c}\text { Percentage of } \\
\text { variance }\end{array}$ & Cumulative \% & totals & $\begin{array}{c}\text { Percentage of } \\
\text { variance }\end{array}$ & Cumulative \% & totals & $\begin{array}{l}\text { Percentage of } \\
\text { variance }\end{array}$ & Cumulative \% \\
\hline 1 & 2.467 & 20.561 & 20.561 & 2.467 & 20.561 & 20.561 & 2.102 & 17.516 & 17.516 \\
\hline 2 & 2.113 & 17.611 & 38.172 & 2.113 & 17.611 & 38.172 & 2.100 & 17.499 & 35.015 \\
\hline 3 & 1.853 & 15.440 & 53.612 & 1.853 & 15.440 & 53.612 & 1.880 & 15.665 & 50.680 \\
\hline 4 & 1.282 & 10.681 & 64.294 & 1.282 & 10.681 & 64.294 & 1.597 & 13.306 & 63.986 \\
\hline 5 & 1.157 & 9.645 & 73.939 & 1.157 & 9.645 & 73.939 & 1.194 & 9.953 & 73.939 \\
\hline 6 & 0.881 & 7.342 & 81.280 & & & & & & \\
\hline 7 & 0.801 & 6.675 & 87.955 & & & & & & \\
\hline 8 & 0.552 & 4.596 & 92.551 & & & & & & \\
\hline 9 & 0.407 & 3.388 & 95.940 & & & & & & \\
\hline 10 & 0.258 & 2.147 & 98.087 & & & & & & \\
\hline 11 & 0.215 & 1.794 & 99.881 & & & & & & \\
\hline 12 & 0.014 & 0.119 & 100.000 & & & & & & \\
\hline
\end{tabular}

Table 5. Composition matrix after rotation.

\begin{tabular}{cccccc}
\hline & 1 & 2 & 3 & 4 & 5 \\
\hline Net cash flow per share & 0.312 & 0.573 & 0.102 & -0.218 & 0.206 \\
Return on equity & -0.017 & 0.438 & 0.748 & 0.009 & 0.271 \\
Operating profit margin & -0.006 & -0.191 & 0.750 & -0.327 & -0.288 \\
Current ratio & 0.975 & 0.011 & 0.088 & 0.036 & -0.028 \\
Quick ratio & 0.976 & 0.022 & 0.036 & 0.077 & -0.026 \\
Growth rate of net profit & -0.247 & 0.161 & 0.176 & -0.387 & 0.675 \\
Growth rate of net assets & -0.054 & 0.854 & 0.130 & 0.096 & 0.058 \\
Growth rate of total assets & -0.052 & 0.838 & -0.060 & 0.151 & -0.232 \\
The turnover rate of inventory & 0.047 & -0.080 & 0.246 & 0.755 & 0.066 \\
The turnover rate of accounts receivable & -0.102 & 0.141 & 0.181 & -0.282 & -0.690 \\
The turnover rate of total assets & 0.032 & 0.229 & -0.198 & 0.753 & -0.024 \\
Net profit cash content & -0.147 & -0.072 & -0.745 & -0.192 & 0.024 \\
\hline
\end{tabular}

which are 0.975 and 0.976 , respectively. Therefore, the first common factor can be named as the solvency factor. The second common factor has the largest cor- 
relation coefficient with the growth rate of net assets, the growth rate of total assets and the net cash flow per share, which are $0.854,0.838$ and 0.573 , respectively. Therefore, the second common factor can be named as the asset growth capacity factor. The correlation coefficient between the third common factor and return on equity, operating profit margin and net profit cash content is the largest, which is $0.784,0.750$ and -0.745 , respectively. Therefore, the third common factor can be named as profitability factor. See Table 4 . The correlation coefficient between the fourth common factor and the turnover rate of inventory and the turnover rate of total assets is the largest, which is 0.755 and 0.753 , respectively. Therefore, the fourth common factor can be named as operation capacity factor. The fifth common factor has the largest correlation coefficient with the turnover rate of accounts receivable and growth rate of net profit, which are -0.690 and 0.675 , respectively. Therefore, the fifth common factor can be named as the development capacity factor. See Table 5 .

According to the component scoring coefficient matrix, the expression between the five main factors and the 12 financial indicators can be established as follows:

$$
\begin{aligned}
F_{1}= & 0.170 Z X_{1}-0.044 Z X_{2}-0.027 Z X_{3}+0.470 Z X_{4}+0.470 Z X_{5} \\
& -0.079 Z X_{6}-0.043 Z X_{7}-0.045 Z X_{8}-0.049 Z X_{9} \\
& -0.061 Z X_{10}-0.036 Z X_{11}-0.014 Z X_{12} \\
F_{2}= & 0.279 Z X_{1}+0.129 Z X_{2}-0.131 Z X_{3}-0.008 Z X_{4}+0.000 Z X_{5} \\
& +0.050 Z X_{6}+0.407 Z X_{7}+0.431 Z X_{8}-0.119 Z X_{9} \\
& +0.114 Z X_{10}+0.085 Z X_{11}+0.049 Z X_{12} \\
F_{3}= & -0.036 Z X_{1}+0.380 Z X_{2}+0.414 Z X_{3}-0.003 Z X_{4}-0.030 Z X_{5} \\
& +0.063 Z X_{6}+0.000 Z X_{7}-0.100 Z X_{8}+0.210 Z X_{9} \\
& +0.070 Z X_{10}-0.071 Z X_{11}-0.422 Z X_{12} \\
F_{4}= & -0.195 Z X_{1}+0.046 Z X_{2}-0.140 Z X_{3}-0.049 Z X_{4}-0.027 Z X_{5} \\
& -0.221 Z X_{6}+0.022 Z X_{7}+0.039 Z X_{8}+0.520 Z X_{9} \\
& -0.179 Z X_{10}+0.459 Z X_{11}-0.174 Z X_{12} \\
F_{5}= & 0.147 Z X_{1}+0.202 Z X_{2}-0.237 Z X_{3}+0.008 Z X_{4}+0.010 Z X_{5} \\
& +0.549 Z X_{6}-0.003 Z X_{7}-0.247 Z X_{8}+0.071 Z X_{9} \\
& -0.600 Z X_{10}-0.024 Z X_{11}-0.018 Z X_{12}
\end{aligned}
$$

\subsection{Multiple Regression Analysis}

This paper studies the stock price fluctuation of Shanghai A-share transportation companies. Transportation industry is the basic industry of our country and an important industry connecting various industries. In the selection of data samples, some ST companies and companies with incomplete data were excluded. Finally, 63 listed companies were selected from 70 listed companies. All index data were obtained from the Resset Financial Research Database.

The stock price of listed companies in the transportation industry in Shanghai 
A-share market after the disclosure of their annual report in 2020 was taken as the explanatory variable, and the five principal components extracted were taken as explanatory variables. Using EVIEWS9.0, the regression equation was established through OLS method, and the following results were obtained ( $\mathrm{Ma} \& \mathrm{Xu}$, 2017):

$$
\begin{gathered}
\hat{P}=8.8889+2.8943 F_{1}+3.5679 F_{2}+2.5808 F_{3}+1.9757 F_{4}+0.0015 F_{5} \\
(1.4685)(1.4681)(1.4695)(1.4675)(1.4689) \\
t=(1.9709)(2.4302)(1.9563)(2.3463)(2.0010) \\
R^{2}=0.2049, \hat{R}^{2}=0.1351, F=2.9369, D W=1.3562
\end{gathered}
$$

At the same time, the following model tests were conducted on the principal component regression results.

\subsubsection{Goodness of Fit Test}

By multiple regression analysis result, the sample can be determined coefficient $R^{2}=0.2049$, the revised samples of determination coefficient $\hat{R}^{2}=0.1351$. The closer $R^{2}$ approaches 1 , the better the fitting degree of the regression equation to the observed value is. The value of $R^{2}$ in this study is too small, so the fitting effect is not very good.

\subsubsection{F Test}

The null hypothesis is: $H_{0}: \beta_{1}=\beta_{2}=\beta_{3}=\beta_{4}=\beta_{5}=0$, the alternative hypothesis for $H_{1}$ : at least one $\beta_{i}$ is not equal to zero $(i=1,2,3,4,5)$. According to the results of multiple regression, $F=2.9369$, under the significance $\alpha=0.05$, the $F$ statistic is greater than the critical value, so the null hypothesis is rejected and the alternative hypothesis is accepted, that is, the overall regression equation is significant.

\subsection{3. t Test}

Propose the null hypothesis for testing: $H_{0}: \beta_{1}=\beta_{2}=\beta_{3}=\beta_{4}=\beta_{5}=0$, the alternative hypothesis for $H_{1}$ : at least one $\beta_{i}$ is not equal to zero $(i=1,2,3,4$, 5). According to the results of multiple regression, the $T$ statistics of $\beta_{1}, \beta_{2}$, $\beta_{3}, \beta_{4}$ and $\beta_{5}$ are $1.9709,2.4302,1.9563,2.3463$ and 0.0010 . Under the significant of alpha $=0.05, t$ statistic the critical value of $1.96,1.9709>1.96,2.4302>$ $1.96,1.9563>1.96,2.3463>1.96,2.0010>1.96$, so reject the null hypothesis and accept the alternative hypothesis, namely the five variables are has a significant influence on stock prices.

\subsubsection{White Inspection}

In order to further enhance the model's persuasiveness and eliminate the possible autocorrelation between explanatory variables of the model, heteroscedasticity test is needed. According to the White test result output by Eviews9.0, Obs ${ }^{\star} \mathrm{R}$-squared $=26.9519$, and the adjoint probability is 0.1366 . When the significance level is $95 \%, 0.1366>0.05$ proves that there is no heteroscedasticity, that is, there is no autocorrelation between explanatory variables. 
After the test of the model is passed, $F_{1}, F_{2}, F_{3}, F_{4}$ and $F_{5}$ are respectively substituted to obtain the regression equation after reduction:

$$
\begin{aligned}
\hat{P}= & 8.8889+1.0095 Z X_{1}+1.4048 Z X_{2}+0.2460 Z X_{3}+1.2272 Z X_{4}+1.2296 Z X_{5} \\
& +0.3235 Z X_{6}+1.3711 Z X_{7}+1.2261 Z X_{8}+1.0030 Z X_{9}+0.0563 Z X_{10} \\
& +0.9227 Z X_{11}+1.2986 Z X_{12}
\end{aligned}
$$

\section{Conclusion and Policy Recommendations}

The analysis shows that the debt paying ability, asset growth ability and profitability of the listed companies in the transportation industry have a significant influence on the stock price fluctuations, and the influence degree is relatively high, followed by the operating capacity index. However, the index related to the company's profit growth ability has a low influence on the stock price fluctuation. Therefore, investors should consider the following factors when making financial investment.

\subsection{Debt Paying Ability and Stock Price}

At the significance level of 5\%, both the liquidity ratio and the speed ratio are significantly positively correlated with the stock price, and the significance coefficients are 1.2272 and 1.2296, respectively, indicating that the stock price increases by 1.2272 and 1.2296 units for each increase of the current ratio and the quick ratio. Compared with the asset growth ability and profitability, the indexes related to debt paying ability have a higher impact on the stock price of the listed companies in the transportation industry, so the fluctuation of stock price is largely related to the index of debt paying ability.

\subsection{Asset Growth Capacity and Stock Price}

At the significance level of 5\%, the growth rate of net assets, growth rate of total assets and net cash flow per share are significantly positively correlated with the stock price, and the significance coefficients are 1.3711, 1.2261 and 1.0095, respectively, indicating that when the growth rate of net assets, growth rate of total assets and net cash flow per share increase by one unit, the stock price will increase by $1.3711,1.2261$ and 1.0095 units, respectively. Generally speaking, the stock price of listed companies in the transportation industry is greatly affected by the company's asset growth ability. Therefore, investors need to focus on the index data related to the asset growth capacity of listed companies when making stock investment.

\subsection{Profitability and Stock Price}

At the significance level of $5 \%$, financial indicators related to profitability are positively correlated with stock prices. The significance coefficient of return on equity is 1.4048 , and the significance coefficient of operating profit margin and net profit cash content are 0.2460 and 1.2986 respectively. That is to say, among the selected profitability indicators, operating profit margin has the least impact 
on stock price changes.

\subsection{Operating Capacity and Stock Price}

At the significance level of 5\%, the correlation between relevant indexes of operating capacity and stock price is low. According to the significance coefficient, the significance coefficient of the turnover rate of inventory is 1.0030 , that is, when the turnover rate of inventory increases by one unit, the stock price will fluctuate upward by 1.0030 units, while the significance coefficient of the turnover rate of total assets is 0.9227 , indicating that the turnover rate of total assets has a low influence on the stock price. When the turnover rate of total assets increases by one unit, the stock price will only rise by 0.9227 units.

\subsection{Development Ability and Stock Price}

At the significance level of 5\%, the turnover rate of accounts receivable is significantly positively correlated with the stock price, and the significance coefficient is 0.0563 , that is, when the turnover rate of accounts receivable increases by one unit, the stock price will rise by 0.0563 units, and the significance coefficient of the growth rate of net profit is 0.3235 , that is, when the growth rate of net profit increases by one unit, the stock price will rise by 0.3235 units. The financial indicators related to the development ability of listed companies in the transportation industry have a low influence on the stock price, but when conducting investment transactions, they are also important reference data reflecting the potential development ability of listed companies.

In conclusion, the most important factors affecting the stock price fluctuations of listed companies in the transportation industry are the indexes related to debt paying ability, asset growth ability and profitability, followed by the indexes related to operation ability, and the indicators related to development ability have a small force. Therefore, investors should pay more attention to the solvency, asset growth and profitability of listed companies when making relevant investment decisions.

\section{Conflicts of Interest}

The author declares no conflicts of interest regarding the publication of this paper.

\section{References}

Dong, X. X. (2011). Empirical Research on Stock Price Influencing Factors Based on Principal Component Analysis-Empirical Data from Small and Medium-Sized Enterprises Board. Accounting Bulletin, No. 36, 64-67.

Hao, C. W. (2018). Using Eviews7.0 Software to Analyze the Impact of China's Listed Companies' Financial Situation on Stock Prices. Modern Marketing, No. 6, 41.

Jing, F. F. (2017). Research on Macroeconomic Factors Influences Stock Price Volatility Based on Improved GARCH-MIDAS Model. Master's Thesis, Xuzhou: China University of Mining and Technology. 
Li, J. J. (2014). Correlation Analysis between Stock Price and Financial Index of Listed Companies. Journal of Huazhong Agricultural University (Social Science Edition), No. 5, 138-143. (In Chinese)

Ma, C. W., \& Xu, N. N. (2017). Econometric Analysis of Haze Influencing Factors Based on Principal Component Regression Method. Journal of Shenyang University (Social Science), 19, 21-24.

Nie, M. M. (2018). Research on the Influencing Factors of Enterprise Stock Prices in the New Third Board Market Based on Principal Component Analysis. Master's Thesis, Beijing: Capital University of Economics and Business.

Sha, Y. Y. (2018). Research on the Correlation between Financial Indicators and Stock Prices of Listed Companies in China. Jinan: Shandong University.

Xiang, S. S., \& Dai, L. (2019). Research on the Influence Factors of Stock Price Fluctuation of A-Share Listed Companies Based on Multiple Linear Regression Analysis. Business Economics, No. 4, 151-152.

Yao, W. Y., \& Wang, F. F. (2014). An Empirical Study on the Influence of Financial Indicators on Stock Prices of Listed Companies. Friends of Accounting, No. 2, 60-62. 